\title{
Pulsatile Insulin Release from Pancreatic Islets with Nonoscillatory Elevation of Cytoplasmic $\mathrm{Ca}^{2+}$
}

\author{
Johanna Westerlund, Erik Gylfe, and Peter Bergsten \\ Department of Medical Cell Biology, University of Uppsala, S-751 23 Uppsala, Sweden
}

\begin{abstract}
The relationship between insulin release and cytoplasmic $\mathrm{Ca}^{2+}$ concentration $\left(\left[\mathrm{Ca}^{2+}\right]_{\mathrm{i}}\right)$ was studied in isolated pancreatic islets from $o b / o b$ mice. Although $\left[\mathrm{Ca}^{2+}\right]_{\mathrm{i}}$ was low and stable in the presence of $3 \mathrm{mM}$ glucose, basal insulin release exhibited low amplitude pulsatility, with a frequency of $0.32 \pm 0.04 \mathrm{~min}^{-1}$. Depolarization by raising $\mathrm{K}^{+}$from 5.9 to $30.9 \mathrm{mM}$ or by the addition of $1 \mathrm{mM}$ tolbutamide caused a pronounced initial insulin pulse followed by declining pulses, but there was no change in frequency. This decline in amplitude of the insulin pulses was prevented in similar experiments performed in the presence of $11 \mathrm{mM}$ glucose. Corresponding measurements of $\left[\mathrm{Ca}^{2+}\right]_{i}$ in islets exposed to tolbutamide or the high $\mathrm{K}^{+}$concentration revealed stable elevations without oscillations. Although the $\left[\mathrm{Ca}^{2+}\right]_{i}$ level is an important determinant for the rate of secretion, the results indicate that pulsatile insulin release does not always depend on $\left[\mathrm{Ca}^{2+}\right]_{i}$ oscillations. It is suggested that cyclic generation of ATP may fuel pulsatile release under conditions when $\left[\mathrm{Ca}^{2+}\right]_{\mathrm{i}}$ remains stable. (J. Clin. Invest. 1997. 100:2547-2551.) Key words: insulin secretion • tolbutamide • depolarization - islets of Langerhans - adenosine triphosphate
\end{abstract}

\section{Introduction}

Pulsatile secretion of insulin has been observed from individual pancreatic islets (1) as well as from the isolated perfused pancreas (2). It is believed that this pulsatility is causing the pronounced oscillations of insulin in the portal vein $(3,4)$ and the more dampened ones in the periphery $(3,5,6)$. Such variations are essential for the effectiveness of the hormone as a hypoglycemic agent (7-9), and the early disappearance of these regular oscillations in type 2 diabetes is associated with insulin resistance and hyperglycemia $(10,11)$.

The regulatory role of the cytoplasmic $\mathrm{Ca}^{2+}$ concentration $\left(\left[\mathrm{Ca}^{2+}\right]_{\mathrm{i}}\right)^{1}$ in insulin secretion is well-established. It was shown

Address correspondence to Dr. Peter Bergsten, Department of Medical Cell Biology, University of Uppsala, Box 571, S-751 23 Uppsala, Sweden. Phone: 46-18-471-4923; FAX: 46-18-471-4059; E-mail: peter.bergsten@medcellbiol.uu.se

Received for publication 10 February 1997 and accepted in revised form 22 September 1997.

1. Abbreviation used in this paper: $\left[\mathrm{Ca}^{2+}\right]_{\mathrm{i}}$, cytoplasmic $\mathrm{Ca}^{2+}$ concentration.

J. Clin. Invest.

(C) The American Society for Clinical Investigation, Inc. 0021-9738/97/11/2547/05 \$2.00

Volume 100, Number 10, November 1997, 2547-2551

http://www.jci.org early that $\mathrm{Ca}^{2+}$ omission $(12,13)$ or addition of blockers of voltage-dependent $\mathrm{Ca}^{2+}$ channels (14) abolishes glucose-stimulated insulin secretion. Moreover, glucose and other stimulators of insulin secretion induce elevation of $\left[\mathrm{Ca}^{2+}\right]_{i}$ in $\beta$ cells (15), and insulin secretion from permeabilized $\beta$ cells is stimulated by a rise in the external $\mathrm{Ca}^{2+}$ concentration (16). Since the discovery that glucose induces large-amplitude oscillations of $\left[\mathrm{Ca}^{2+}\right]_{\mathrm{i}}$ in individual $\beta$ cells (17), it has been demonstrated that these oscillations spread by gap-junctional coupling to neighboring cells (18) and become synchronized in the entire pancreatic islet (19). With the development of a sensitive ELISA (1), it was possible to verify that these oscillations occur in synchrony with pulsatile release of insulin (19). Consequently, there is strong evidence supporting an imperative role for $\mathrm{Ca}^{2+}$ as an initiator of insulin secretion.

Circulating insulin not only oscillates postprandially; there are also regular variations of insulin in the fasting state $(4,5$, $20)$. Since $\beta$ cells and pancreatic islets show low and stable $\left[\mathrm{Ca}^{2+}\right]_{\mathrm{i}}$ at nonstimulatory glucose concentrations (17-19), it is tempting to attribute the insulin oscillations in the fasting state to a small basal secretion stimulated by the combined effect of different nutrients and hormones like glucagon. However, we also found recently that basal secretion of insulin from individual pancreatic islets exposed to nutrient-free medium exhibits pulsatile release of insulin despite a low and stable $\left[\mathrm{Ca}^{2+}\right]_{i}(21)$.

We have now examined further the relationship between $\left[\mathrm{Ca}^{2+}\right]_{\mathrm{i}}$ and insulin secretion in individual pancreatic islets depolarized by exposure to the hypoglycemic sulfonylurea tolbutamide or to a high concentration of $\mathrm{K}^{+}$. Both of these conditions are known to be associated with a sustained elevation of $\left[\mathrm{Ca}^{2+}\right]_{\mathrm{i}}$. It was found that this stable elevation of $\left[\mathrm{Ca}^{2+}\right]_{\mathrm{i}}$ had a dramatic effect in transforming the tiny basal insulin pulses into much more pronounced ones. This observation seems to indicate a more permissive role for $\mathrm{Ca}^{2+}$ in insulin secretion. Since sulfonylureas are commonly used antidiabetic agents, it is advantageous that they do not interfere with pulsatile insulin release, which is considered important for keeping the hormone receptors upregulated (22).

\section{Methods}

Materials. Reagents of analytical grade and deionized water were used. Collagenase, Hepes, and BSA (fraction V) were obtained from Boehringer Mannheim GmbH (Mannheim, Germany). Tetramethylbenzidine and insulin peroxidase came from Sigma Chemical Co. (St. Louis, MO). The rat insulin standard was from Novo Nordisk A/S (Bagsvaerd, Denmark). IgG-certified microtiter plates were purchased from Nunc, Inc. (Roskilde, Denmark). Tolbutamide was a gift from Hoechst AG (Frankfurt, Germany). The mouse insulin antibodies were raised in our laboratory in guinea pigs.

General design of experiments. Pancreatic islets were collagenase-isolated from overnight-starved $o b / o b$ mice taken from a local colony (23). Islets used for the combined measurements of $\left[\mathrm{Ca}^{2+}\right]_{\mathrm{i}}$ and insulin release were cultured overnight in RPMI 1640 medium supplemented with $5.5 \mathrm{mM}$ glucose and $10 \%$ FCS, whereas freshly isolated islets were used when measuring insulin release alone. All 
perifusions were performed in a medium supplemented with $1 \mathrm{mg} / \mathrm{ml}$ albumin and containing (mM): $\mathrm{NaCl} 125, \mathrm{KCl} 5.9, \mathrm{MgCl}_{2} 1.2, \mathrm{CaCl}_{2}$ 1.28 , and Hepes 25, titrated to $\mathrm{pH} 7.4$ with $\mathrm{NaOH}$. When $\mathrm{KCl}$ was increased to $30.9 \mathrm{mM}, \mathrm{NaCl}$ was isoosmotically reduced.

Combined measurements of cytoplasmic $\mathrm{Ca}^{2+}$ and insulin release. The combined measurements were performed adhering to a previous protocol (24). A single islet was loaded with the acetoxymethyl ester of fura-2 $(2 \mu \mathrm{M})$ for $40 \mathrm{~min}$ in the presence of $3 \mathrm{mM}$ glucose. After rinsing, the islet was allowed to attach to the central part of a coverslip coated with poly-L-lysine. The coverslip was part of a $15-\mu l$ perifusion chamber that was placed on the stage of an inverted microscope (Diaphot; Nikon Inc., Melville, NY) within a climate box maintained at $37^{\circ} \mathrm{C}$. The microscope was equipped for epifluorescence fluorometry with a 400-nm dichroic mirror, a $\times 100$ ultraviolet fluorite objective, and a photomultiplier. The islet was perifused at a rate of $150-200 \mu \mathrm{l} / \mathrm{min}$, and $\left[\mathrm{Ca}^{2+}\right]_{i}$ was recorded with dual wavelength fluorometry, with excitation at 340 and $380 \mathrm{~nm}$ and emission at $510 \mathrm{~nm}$ (25). For determination of insulin, the perifusate was collected in 20-s fractions that were cooled immediately on ice.

Measurements of insulin release alone. The kinetics of insulin release alone were studied as described previously (1). A single islet was placed in a thermostated $\left(37^{\circ} \mathrm{C}\right) 10-\mu \mathrm{l}$ chamber and perifused at a rate of $150-200 \mu \mathrm{l} / \mathrm{min}$ with medium containing $3 \mathrm{mM}$ glucose. After 60-75 min of introductory perifusion, the perifusate was collected in 20-s fractions and cooled immediately on ice. Insulin was assayed by a competitive ELISA with the insulin antibody immobilized directly onto the solid phase (1). Amounts of insulin down to 100 amol were obtained from linear standard curves in semilogarithmic plots. The rate of insulin release was normalized to dry weight after freeze-drying and weighing the islets on a quartz fiber balance. To assure that the amounts of insulin in each fraction were within the linear part of the standard curve, islets weighing between 5 and $10 \mu \mathrm{g}$ were selected.

Data analysis. The frequencies of pulsatile insulin release were analyzed by Fourier transformation using Igor software (WaveMetrics, Lake Oswego, OR). The figures show three point moving averages. Other data are presented as means \pm SEM. Differences in secretory rates and frequencies were evaluated with Student's $t$ test for paired observations.

\section{Results}

The effects of depolarization on $\left[\mathrm{Ca}^{2+}\right]_{\mathrm{i}}$ and insulin release were studied simultaneously in individual pancreatic islets that had been cultured overnight in the presence of $5.5 \mathrm{mM}$ glucose. During subsequent perifusion with medium containing $3 \mathrm{mM}$ glucose, increase in the $\mathrm{K}^{+}$concentration from 5.9 to 30.9 $\mathrm{mM}$ (Fig. 1) or addition of $1 \mathrm{mM}$ tolbutamide (Fig. 2) caused elevation of $\left[\mathrm{Ca}^{2+}\right]_{i}$ paralleled by marked stimulation of insulin release. However, whereas the elevation of $\left[\mathrm{Ca}^{2+}\right]_{i}$ was sustained, the stimulated release of insulin occurred in pronounced pulses, with gradually decreasing amplitudes and frequencies of $0.2-0.3 \mathrm{~min}^{-1}$. In four out of five cultured islets, increase in the glucose concentration from 3 to $11 \mathrm{mM}$ induced synchronized oscillations in $\left[\mathrm{Ca}^{2+}\right]_{\mathrm{i}}$ and insulin release (Fig. $3 A$ ), whereas a small sustained increase in $\left[\mathrm{Ca}^{2+}\right]_{\mathrm{i}}$ was observed in the remaining islet (Fig. $3 \mathrm{~B}$ ). However, this islet also had pulsatile release of insulin, although the amplitude was half of that in the islets with $\left[\mathrm{Ca}^{2+}\right]_{\mathrm{i}}$ oscillations. The subsequent introduction of $1 \mathrm{mM}$ tolbutamide caused a prompt sustained increase in $\left[\mathrm{Ca}^{2+}\right]_{\mathrm{i}}$ (Fig. 3). The corresponding measurements of insulin showed pulses with the same frequency as those observed in the presence of $11 \mathrm{mM}$ glucose, but with larger amplitudes.

The kinetics of insulin release were studied further in

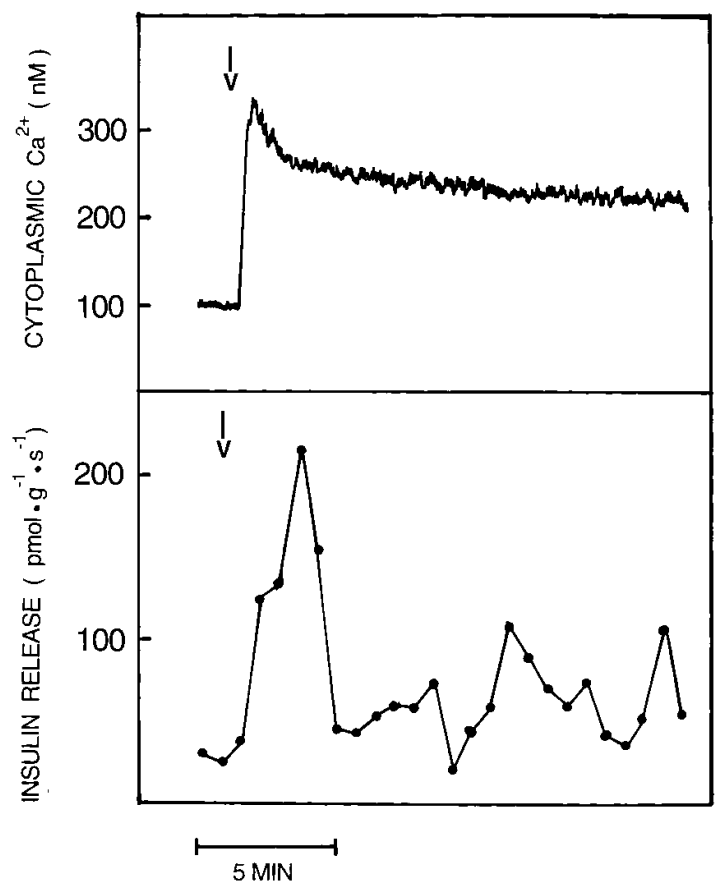

Figure 1. Effects of $\mathrm{K}^{+}$depolarization on $\left[\mathrm{Ca}^{2+}\right]_{\mathrm{i}}($ top $)$ and insulin release (bottom) of an individual pancreatic islet. The islet was cultured overnight in the presence of $5.5 \mathrm{mM}$ glucose and loaded with the $\mathrm{Ca}^{2+}$ indicator fura- 2 for an incubation of $40 \mathrm{~min}$ in medium containing $3 \mathrm{mM}$ glucose. The traces start after subsequent perifusion for $20 \mathrm{~min}$ in similar medium lacking indicator. Arrows, Elevation of $\mathrm{K}^{+}$concentration from 5.9 to $30.9 \mathrm{mM}$. Representative experiment of four.

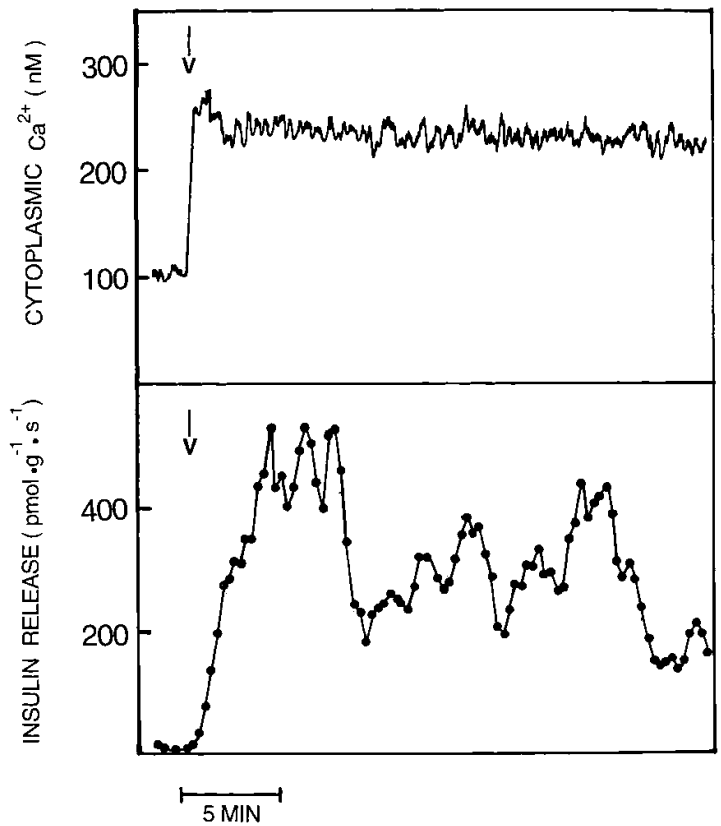

Figure 2. Effects of tolbutamide depolarization on $\left[\mathrm{Ca}^{2+}\right]_{\mathrm{i}}($ top $)$ and insulin release (bottom) of an individual pancreatic islet. The islet was cultured overnight in the presence of $5.5 \mathrm{mM}$ glucose and loaded with the $\mathrm{Ca}^{2+}$ indicator fura- 2 for an incubation of $40 \mathrm{~min}$ in medium containing $3 \mathrm{mM}$ glucose. The traces start after subsequent perifusion for $20 \mathrm{~min}$ in similar medium lacking indicator. Arrows, Addition of $1 \mathrm{mM}$ tolbutamide. Representative experiment of four. 

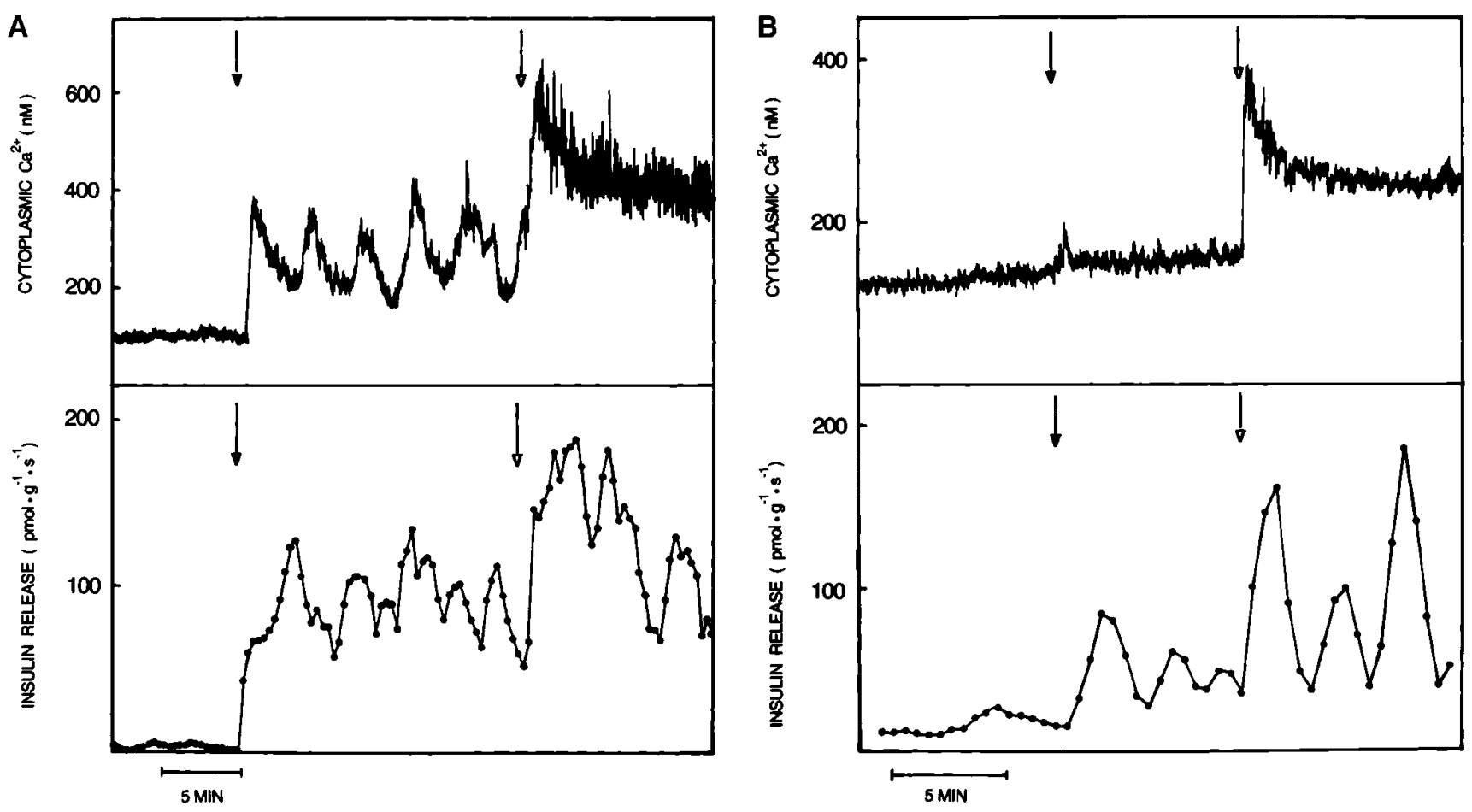

Figure 3. Effects of tolbutamide depolarization on $\left[\mathrm{Ca}^{2+}\right]_{\mathrm{i}}$ (top panels) and insulin release (bottom panels) of individual pancreatic islets exposed to $11 \mathrm{mM}$ glucose. Each islet was cultured overnight in the presence of $5.5 \mathrm{mM}$ glucose and loaded with the $\mathrm{Ca}^{2+}$ indicator fura- 2 for an incubation of $40 \mathrm{~min}$ in medium containing $3 \mathrm{mM}$ glucose. The traces start after subsequent perifusion for 20 min in similar medium lacking indicator. Closed arrows, Increase of glucose concentration to $11 \mathrm{mM}$. Open arrows, Addition of $1 \mathrm{mM}$ tolbutamide. Representative experiment of four $(A)$ and one $(B)$ out of five.

freshly isolated islets. Basal secretion from islets exposed to $3 \mathrm{mM}$ glucose alone exhibited tiny insulin pulses with a frequency of $\sim 0.3 \mathrm{~min}^{-1}$ (Fig. 4 and Table I). After the introduction of $1 \mathrm{mM}$ tolbutamide, pulsatile insulin release continued without change in frequency. However, the amplitude of the first tolbutamide-stimulated insulin pulse was $>50$-fold higher, followed by markedly declining pulses (Fig. 4). The average rate of secretion during the first 10 -min period after tol-

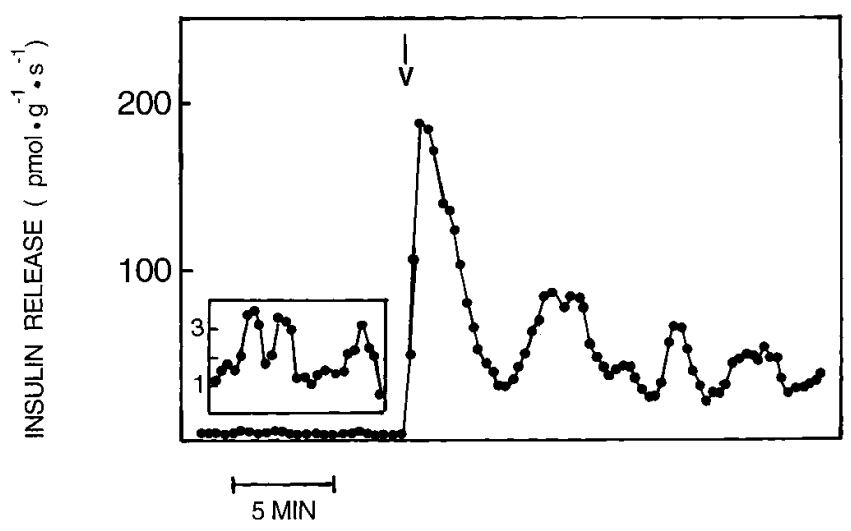

Figure 4. Effect of tolbutamide depolarization on insulin release from a freshly isolated individual pancreatic islet exposed to $3 \mathrm{mM}$ glucose. Before the start of the trace, the islet was perifused for 60 min in $3 \mathrm{mM}$ glucose. Arrow, Addition of $1 \mathrm{mM}$ tolbutamide. Inset, Basal insulin secretion on an expanded scale. Representative experiment of four. butamide stimulation was almost twice that of the subsequent 10-min period (Table I).

Individual freshly isolated pancreatic islets exposed to $11 \mathrm{mM}$ glucose exhibited insulin pulses with similar frequencies but much higher amplitude than those exposed to $3 \mathrm{mM}$ glucose (Figs. 4 and 5). Although the secretory response to $11 \mathrm{mM}$ glucose was sometimes not very prominent (Fig. $5 \mathrm{~B}$ ), the average rate of secretion was 17 -fold higher than at $3 \mathrm{mM}$ (Table I). Both the amplitude of the insulin pulses and the average rate of secretion were increased further by the introduction of $1 \mathrm{mM}$ tolbutamide. This increase was particularly pronounced in cells with a small response to $11 \mathrm{mM}$ glucose (Fig. $5 \mathrm{~B}$ ). Unlike the situation with $3 \mathrm{mM}$ glucose, there was no decline in tolbutamide response between the two consecutive 10-min periods after introduction of the drug (Table I).

\section{Discussion}

The early events in glucose-induced depolarization of the insulin-releasing $\beta$ cells involve metabolism of the sugar with an increase in the ATP/ADP ratio, which results in closure of $\mathrm{K}^{+}$ channels sensitive to this ratio ( $\mathrm{K}_{\mathrm{ATP}}$ channels; reference 26$)$. It is not until the depolarization has reached a certain threshold that voltage-dependent $\mathrm{Ca}^{2+}$ channels open and there is an increase in $\left[\mathrm{Ca}^{2+}\right]_{i}$ (27). Since individual glucose-stimulated $\beta$ cells react with large-amplitude oscillations of $\left[\mathrm{Ca}^{2+}\right]_{i}$, it is possible that these oscillations are determined by oscillations in the ATP/ADP ratio. When investigating this alternative, it is important to keep in mind that elevation of $\left[\mathrm{Ca}^{2+}\right]_{i}$ per se has been found to stimulate $\beta$ cell metabolism (28), and, conse- 
Table 1. Effects of Tolbutamide on Pulsatile Insulin Release from Individual Pancreatic Islets Exposed to 3 or $11 \mathrm{mM}$ Glucose

\begin{tabular}{lccccr}
\hline $\begin{array}{c}\text { Tolbutamide } \\
\text { exposure time }\end{array}$ & Glucose & Tolbutamide & \multicolumn{2}{c}{ Insulin release } & \\
\hline $\min$ & $m M$ & $m M$ & $\mathrm{pmol} \cdot \mathrm{g}^{-1} \cdot \mathrm{s}^{-1}$ & Osc $\cdot \mathrm{min}^{-1}$ & $n$ \\
0 (Control) & 3 & - & $8 \pm 2$ & $0.32 \pm 0.04$ & 17 \\
$0-10$ & 3 & 1 & $52 \pm 16^{*}$ & $0.34 \pm 0.04$ & 7 \\
$10-20$ & 3 & 1 & $30 \pm 9^{*}$ & $0.35 \pm 0.05$ & 8 \\
$0($ Control $)$ & 11 & - & $166 \pm 58$ & $0.28 \pm 0.05$ & 10 \\
$0-10$ & 11 & 1 & $255 \pm 79^{\ddagger}$ & $0.24 \pm 0.02$ & 10 \\
$10-20$ & 11 & 1 & $224 \pm 52$ & $0.28 \pm 0.06$ & 9 \\
& & & & &
\end{tabular}

Freshly isolated individual islets were first perifused for $75 \mathrm{~min}$ with medium containing $3 \mathrm{mM}$ glucose. In the $3-\mathrm{mM}$ glucose experiments, this was followed by addition of $1 \mathrm{mM}$ tolbutamide. In the 11-mM glucose experiments, the first perifusion in $3 \mathrm{mM}$ glucose was followed by elevation of the glucose concentration to $11 \mathrm{mM}$ for $20 \mathrm{~min}$ before the introduction of tolbutamide. The average rates of insulin release were determined during the 10-min periods before the addition of tolbutamide (Controls) and during two consecutive 10-min periods after introduction of the drug. Mean values \pm SEM for the indicated number of experiments $(n) .{ }^{\sharp} P<0.05, * P<0.025$ versus preceding line. In all cases, 11 $\mathrm{mM}$ glucose stimulated insulin secretion significantly compared with 3 $\mathrm{mM}$ glucose $(P<0.001)$. Osc, Oscillations.

quently, oscillations in the ATP/ADP ratio may result from rather than cause oscillations in $\left[\mathrm{Ca}^{2+}\right]_{i}$. However, using the activity of the $\mathrm{K}_{\mathrm{ATP}}$ channels as indicator of the ATP/ADP ratio, it was possible to obtain evidence for primary oscillations of metabolism in $\beta$ cells with stable and low $\left[\mathrm{Ca}^{2+}\right]_{i}$ during exposure to nonstimulatory concentrations of glucose (29).

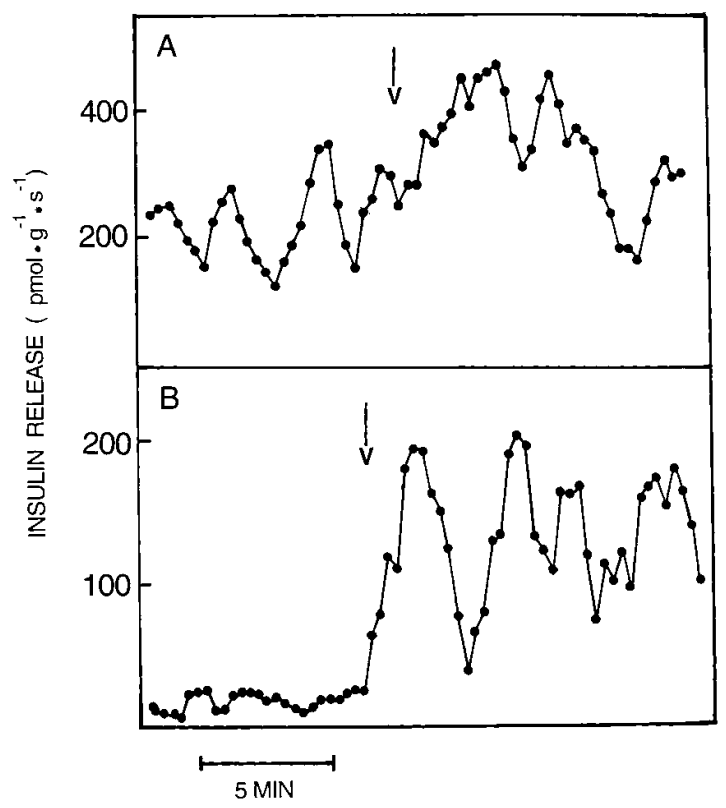

Figure 5. Effect of tolbutamide depolarization on insulin release from freshly isolated individual pancreatic islets exposed to $11 \mathrm{mM}$ glucose. Before the start of the trace, the islets were perifused for 75 min in $3 \mathrm{mM}$ glucose, followed by $20 \mathrm{~min}$ in $11 \mathrm{mM}$ glucose. Arrows, Addition of $1 \mathrm{mM}$ tolbutamide. Two of five experiments.
In pancreatic islets exposed to intermediary glucose concentrations, the $\left[\mathrm{Ca}^{2+}\right]_{\mathrm{i}}$ oscillations occur in parallel with pulsatile release of insulin (19). In these experiments, $\left[\mathrm{Ca}^{2+}\right]_{i}$ was elevated, avoiding induction of oscillations. This was accomplished by exposure to the hypoglycemic sulfonylurea, tolbutamide, or by $\mathrm{K}^{+}$depolarization. Sulfonylureas depolarize $\beta$ cells by closing the $\mathrm{K}_{\mathrm{ATP}}$ channels, thus preventing any effect of the ATP/ADP ratio on membrane potential. The concentration of tolbutamide used $(1 \mathrm{mM})$ was sufficient for closing all $\mathrm{K}_{\mathrm{ATP}}$ channels, even in $\beta$ cells exposed to only $3 \mathrm{mM}$ of glucose (30). When $\beta$ cells are instead depolarized by elevating the external $\mathrm{K}^{+}$concentration, the importance of the ATP/ADP ratio as a regulator of $\mathrm{Ca}^{2+}$ influx is marginal. Our data indicate that pulsatile insulin secretion persists when $\left[\mathrm{Ca}^{2+}\right]_{i}$ is elevated to a sustained and stable level by tolbutamide or $\mathrm{K}^{+}$depolarization. Similar dissociation between $\left[\mathrm{Ca}^{2+}\right]_{\mathrm{i}}$ oscillations and pulsatile insulin release has been found when examining the detailed kinetics of basal insulin release or the maximal secretion in response to glucose. In both cases, pulsatile insulin release was found under conditions usually associated with stable levels of $\left[\mathrm{Ca}^{2+}\right]_{i}(21,24)$.

In view of the strong evidence that $\mathrm{Ca}^{2+}$ is an initiator of insulin secretion, and that oscillations in $\left[\mathrm{Ca}^{2+}\right]_{\mathrm{i}}$ always seem to be paralleled by pulsatile release of insulin, the observed dissociation may seem puzzling. This enigma can be understood when considering that the oscillations of $\left[\mathrm{Ca}^{2+}\right]_{i}$ in the $\beta$ cells are caused by variations in the ATP/ADP ratio. However, the ATP/ADP ratio is not only important for the membrane potential in determining $\left[\mathrm{Ca}^{2+}\right]_{i}$. As an energy-requiring process, the exocytosis of insulin is also directly dependent on the ATP/ ADP ratio. It has been proposed that the final docking/fusion of the insulin granules with the plasma membrane is a $\mathrm{Ca}^{2+}$ regulated process, whereas both $\mathrm{Ca}^{2+}$ and ATP are required for the translocation of the granules to the docking site (31). Therefore, parallel oscillations in $\left[\mathrm{Ca}^{2+}\right]_{\mathrm{i}}$ and ATP/ADP ratio would act synergistically to stimulate pulsatile release of insulin. This synergy may be amplified further by putative oscillations in cAMP, since glucose stimulates slightly the formation of this potentiating nucleotide $(32,33)$. Regarding both $\left[\mathrm{Ca}^{2+}\right]_{i}$ and the ATP/ADP ratio as messengers for insulin secretion, it is possible to understand pulsatile release of insulin when one of these factors is oscillating while the other is stable. In islets exposed to low glucose concentrations, the depolarizations obtained by oscillations in the ATP/ADP ratio are insufficient for causing elevation of $\left[\mathrm{Ca}^{2+}\right]_{\mathrm{i}}$. Therefore, the tiny pulses of insulin release in this situation rely entirely on the variations in energy supply. It has been shown previously that nutrientunstimulated islets respond to depolarization with monophasic release of insulin (34), and we have now found that tolbutamide or $\mathrm{K}^{+}$depolarization in the presence of $3 \mathrm{mM}$ glucose induced a pronounced initial insulin pulse followed by pulses with declining amplitudes. The elevation of $\left[\mathrm{Ca}^{2+}\right]_{i}$ obtained by depolarization is apparently a strong stimulus for initial release of insulin, whereas the energy supply is insufficient for maintaining the amplitude of the insulin pulses. In the presence of $11 \mathrm{mM}$ glucose, the oscillations of $\left[\mathrm{Ca}^{2+}\right]_{i}$ and pulsatile release of insulin often coincide (19). Further depolarization with tolbutamide was now found to cause sustained elevation of $\left[\mathrm{Ca}^{2+}\right]_{i}$, but to increase the amplitude of the insulin pulses. In this case, the amplitude was maintained, indicating that the energy supply is not limiting.

Because they keep the insulin receptors upregulated (22), 
oscillations in circulating insulin are considered important for preventing insulin resistance (35). These data indicate that the pulsatile release of insulin underlying these regular variations in the hormone level does not depend entirely on oscillations in $\left[\mathrm{Ca}^{2+}\right]_{i}$. Oscillations in the ATP/ADP ratio, which probably explain the oscillations in $\left[\mathrm{Ca}^{2+}\right]_{i}$, may also have direct effects on the energy-requiring secretion of insulin. Since sulfonylureas are commonly used antidiabetic agents, it is advantageous that they do not interfere with pulsatile insulin release, although they can transform $\left[\mathrm{Ca}^{2+}\right]_{\mathrm{i}}$ oscillations into sustained increase.

\section{Acknowledgments}

The authors are grateful to Kristina Mustajärvi and Else-Marie Andersson for their skillful technical assistance.

This study was supported by grants from the Swedish Medical Research Council (12X-6240 and 12X-11203), the Novo Nordisk Foundation, the Swedish Diabetes Association, and the Family Ernfors Foundation.

\section{References}

1. Bergsten, P., and B. Hellman. 1993. Glucose-induced amplitude regulation of pulsatile insulin secretion from individual pancreatic islets. Diabetes. 42 : 670-674.

2. Stagner, J.I., E. Samols, and G.C. Weir. 1980. Sustained oscillations of insulin glucagon and somatostatin from the isolated canine pancreas during exposure to a constant glucose concentration. J. Clin. Invest. 65:939-942.

3. Jaspan, J.B., E. Lever, K.S. Polonsky, and E. Van Cauter. 1986. In vivo pulsatility of pancreatic islet peptides. Am. J. Physiol. 251:E215-E226.

4. Pørksen, N., S. Munn, J. Steers, S. Vore, J. Veldhuis, and P. Butler. 1995. Pulsatile insulin secretion accounts for $70 \%$ of total insulin secretion during fasting. Am. J. Physiol. 269:E478-E488.

5. Lang, D.A., D.R. Matthews, J. Peto, and R.C. Turner. 1979. Cyclic oscillations of basal plasma glucose and insulin concentrations in human beings. $N$. Engl. J. Med. 301:1023-1027.

6. Goodner, C.J., B.C. Walike, D.J. Koerker, J.W. Ensinck, A.C. Brown, E.W. Chideckel, J. Palmer, and L. Kalnasy. 1977. Insulin, glucagon and glucose exhibits synchronous sustained oscillations in fasting monkeys. Science. 195: 177-179.

7. Lefèbvre, P.J., G. Paolisso, A.J. Scheen, and J.C. Henquin. 1987. Pulsatility of insulin and glucagon release: physiological significance and pharmacological implications. Diabetologia. 30:443-452.

8. Matthews, D.R., B.A. Naylor, R.G. Jones, G.M. Ward, and R.C. Turner. 1983. Pulsatile insulin has greater hypoglycemic effect than continuous delivery. Diabetes. 32:617-621.

9. Paolisso, G., S. Sgambato, R. Torella, M. Varricchio, A.J. Scheen, F. D'Onofrio, and P.J. Lefèbvre. 1988. Pulsatile insulin delivery is more efficient than continuous infusion in modulating islet cell function in normal subjects and patients with type 1 diabetes. J. Clin. Endocrinol. Metab. 66:1220-1226.

10. Lang, D.A., D.R. Matthews, M. Burnett, and R.C. Turner. 1981. Brief, irregular oscillations of basal plasma insulin and glucose concentrations in diabetic man. Diabetes. 30:435-439.

11. O'Rahilly, S., R.C. Turner, and D.R. Matthews. 1988. Impaired pulsatile secretion of insulin in relatives of patients with non-insulin-dependent diabetes. N. Engl. J. Med. 318:1225-1230.

12. Grodsky, G.M., and L.L. Bennett. 1966. Cation requirements for insulin secretion in the isolated perfused pancreas. Diabetes. 15:910-912.

13. Milner, R.D.G., and C.N. Hales. 1967. The role of calcium and magne- sium in insulin secretion from rabbit pancreas studied in vitro. Diabetologia. 3:47-49.

14. Devis, G., G. Somers, E. Van Obberghen, and W.J. Malaisse. 1975. Calcium antagonists and islet function. I. Inhibition of insulin release by verapamil. Diabetes. 24:247-251.

15. Gylfe, E. 1988. Nutrient secretagogues induce bimodal early changes in cytoplasmic calcium of insulin-releasing ob/ob mouse $\beta$-cells. J. Biol. Chem. 263:13750-13754.

16. Yaseen, M.A., K.C. Pedley, and S.L. Howell. 1982. Regulation of insulin secretion from islets of Langerhans rendered permeable by electric discharge. Biochem. J. 206:81-87.

17. Grapengiesser, E., E. Gylfe, and B. Hellman. 1988. Glucose-induced oscillations of cytoplasmic $\mathrm{Ca}^{2+}$ in the pancreatic $\beta$-cell. Biochem. Biophys. Res. Commun. 151:1299-1304.

18. Gylfe, E., E. Grapengiesser, and B. Hellman. 1991. Propagation of cytoplasmic $\mathrm{Ca}^{2+}$ oscillations in clusters of pancreatic $\beta$-cells exposed to glucose. Cell Calcium. 12:229-240.

19. Bergsten, P., E. Grapengiesser, E. Gylfe, A. Tengholm, and B. Hellman 1994. Synchronous oscillations of cytoplasmic $\mathrm{Ca}^{2+}$ and insulin release in glucose-stimulated pancreatic islets. J. Biol. Chem. 269:8749-8753.

20. Lang, D.A., D.R. Matthews, M. Burnett, G.M. Ward, and R.C. Turner. 1982. Pulsatile, synchronous basal insulin and glucagon secretion in man. Diabetes. 31:22-26.

21. Westerlund, J., B. Hellman, and P. Bergsten. 1996. Pulsatile insulin release from mouse islets occurs in the absence of stimulated entry of $\mathrm{Ca}^{2+} . J$ Clin. Invest. 97:1860-1863.

22. Goodner, C.J., I.R. Sweet, and H.C. Harrison. 1988. Rapid reduction and return of surface insulin receptors after exposure to brief pulses of insulin in perifused rat hepatocytes. Diabetes. 37:1316-1323.

23. Hellman, B. 1965. Studies in obese-hyperglycemic mice. Ann. NY Acad. Sci. 131:541-558.

24. Bergsten, P. 1995. Slow and fast oscillations of cytoplasmic $\mathrm{Ca}^{2+}$ in pancreatic islets correspond to pulsatile insulin release. Am. J. Physiol. 268:E282E287.

25. Grynkiewicz, G., M. Poenie, and R.Y. Tsien. 1985. A new generation of $\mathrm{Ca}^{2+}$ indicators with greatly improved fluorescence properties. J. Biol. Chem. 260:3440-3450.

26. Ashcroft, F.M., and P. Rorsman. 1989. Electrophysiology of the pancreatic $\beta$-cell. Prog. Biophys. Mol. Biol. 54:87-143.

27. Chow, R.H., P.E. Lund, S. Löser, U. Panten, and E. Gylfe. 1995. Coincidence of early glucose-induced depolarization with lowering of cytoplasmic $\mathrm{Ca}^{2+}$ in mouse pancreatic $\beta$-cells. J. Physiol. (Lond). 485:607-617.

28. Pralong, W.F., A. Spät, and C.B. Wollheim. 1994. Dynamic pacing of cell metabolism by intracellular $\mathrm{Ca}^{2+}$ transients. J. Biol. Chem. 269:2731027314.

29. Dryselius, S., P.E. Lund, E. Gylfe, and B. Hellman. 1994. Variations in ATP-sensitive $\mathrm{K}^{+}$channel activity provide evidence for inherent metabolic oscillations in pancreatic $\beta$-cells. Biochem. Biophys. Res. Commun. 205:880-885.

30. Trube, G., P. Rorsman, and T. Ohno-Shosaku. 1986. Opposite effects of tolbutamide and diazoxide on the ATP-dependent $\mathrm{K}^{+}$channel in mouse pancreatic $\beta$-cells. Pflügers Arch. 407:493-499.

31. Renström, E., L. Eliasson, K. Bokvist, and P. Rorsman. 1996. Cooling inhibits exocytosis in single mouse pancreatic B-cells by suppression of granule mobilization. J. Physiol. (Lond). 494:41-52.

32. Grill, V., and E. Cerasi. 1973. Activation by glucose of adenyl cyclase in pancreatic islets of the rat. FEBS (Fed. Eur. Biochem. Soc.) Lett. 33:311-314.

33. Hellman, B., L.Å. Idahl, A. Lernmark, and I.B. Täljedal. 1974. The pancreatic $\beta$-cell recognition of insulin secretagogues: does cyclic AMP mediate the effect of glucose? Proc. Natl. Acad. Sci. (USA). 71:3405-3409.

34. Gembal, M., P. Detimary, P. Gilon, Z.Y. Gao, and J.C. Henquin. 1993. Mechanisms by which glucose can control insulin release independently from its action on adenosine triphosphate-sensitive $\mathrm{K}^{+}$channels in mouse B cells. $J$. Clin. Invest. 91:871-880.

35. Peiris, A.N., J.I. Stagner, R.L. Vogel, A. Nakagawa, and E. Samols. 1992. Body fat distribution and peripheral insulin sensitivity in healthy men: role of insulin pulsatility. J. Clin. Endocrinol. Metab. 75:290-294. 